\title{
Cenários e perspectivas das principais culturas do Rio Grande do Sul em processos de biorrefinaria
}

\author{
Douglas Faria ${ }^{1 *}$, Grazielle Machado ${ }^{1}$, Paulo Eichler ${ }^{1}$, Bruna Boneberg ${ }^{1}$, Fernanda Raye ${ }^{1}$, \\ Matheus Vilares ${ }^{1}$, Leandro Gomes ${ }^{1}$ e Fernando Santos ${ }^{1}$
}

'Centro de Estudos em Biorrefinaria, Universidade Estadual do Rio Grande do Sul - Unidade de Novo Hamburgo, Rua Inconfidentes, 395, Bairro Primavera, CEP: 93340-140, RS. E-mail: douglas.faria_05@hotmail.com

ISSN 2448-0479

Resumo - O grande desafio da civilização moderna é se tornar uma sociedade mais sustentável, baseada no uso racional dos recursos naturais. Nesse contexto, surgiu o conceito de biorrefinaria, que prevê a conversão da biomassa em biocombustíveis, biomateriais, bioquímicos e bioenergia com baixo desperdício e mínimas emissóes. No que diz respeito à produção de biomassas, o Brasil é considerado uma referência mundial pela sua avançada tecnologia agrícola e florestal, vasta disponibilidade de terra arável e condiçóes edafoclimáticas favoráveis em comparação com outras partes do mundo. Nesse cenário, o estado do Rio Grande do Sul (RS) é considerado um grande centro para o desenvolvimento, aperfeiçoamento e implementaçáo de tecnologias que visem converter a biomassa lignocelulósica em produtos através $\mathrm{da}$ biorrefinaria. Nessa expectativa, o aproveitamento dos resíduos provenientes das culturas de eucalipto, tabaco, milho, uva, soja e arroz que hoje em dia são gerados em quantidades significativas, devem aumentar consideravelmente nos próximos anos, transformando-os de fontes de custos para fontes de receitas. Neste contexto, o objetivo do presente trabalho foi fazer uma revisão do potencial energético e químico das principais culturas do RS e sua utilizaçáo através dos processos químicos, bioquímicos e termoquímicos.

Palavras-chave - Biorrefinaria. Biomassa. Celulose.

Abstract - The great challenge of the modern civilization is become a more sustainable society, based on the rational use of the natural resources. In this con- text, the biorefinery concept arose, which provides the biomass conversion in biofuels, biomaterials, biochemicals and bioenergy with low wastage and minimum emissions. As regards to biomass production, Brazil is considered a global reference because of its advanced agricultural and forestry technologies, wide availability of arable land and favorable climate conditions compared to other parts of the world. In this scenario, the RS state is considered a great center to development, improvement and implementation of technologies that aim to convert lignocellulosic biomass into products through biorefinary. In this expectation, the use of waste from the eucalyptus crops, tobacco, corn, grape, soy and rice that nowadays are being generated in significant amounts, should increase considerably in the next years, turning them from cost sources to revenue sources. In that context, the objective of this study was to review energetic and chemical potential of the main crops of the RS state and its use through chemical, biochemical and thermochemical processes.

Keywords - Biorefinery. Biomass. Cellulose.

Recebido em: 17 de agosto de 2016

Aprovado em: 05 de dezembro de 2016

\section{INTRODUÇÃO}

À medida que a matéria-prima proveniente de fontes não renováveis irreversivelmente diminui, surge a necessidade de uma progressiva mudança nas in- 
dústrias para buscarem matérias-primas de fontes renováveis (CHERUBINI, 2010). No Brasil, uma das fontes renováveis de maior abundância é a biomassa lignocelulósica, onde, segundo o Balanço Energético Nacional de 2013, representa cerca de 25\% da oferta interna de energia nacional - mais da metade da oferta de todos recursos renováveis somados (40\%) - (EMPRESA DE PESQUISA ENERGÉTICA, 2013).

De acordo com as definiçóes de terras agrícolas pela Organização das Naçóes Unidas para Agricultura e Alimentação (FAO) a agricultura ocupa um terço da superfície de terra no mundo, visto que é uma atividade de vital importância para sobrevivência humana (FOOD AND AGRICULTURE ORGANIZATION OF THE UNITED NATIONS, 2015). O crescimento do agronegócio mundial coloca o setor em destaque no processo de desenvolvimento do país. Desta forma, surgem inovaçôes tecnológicas e maior conhecimento da área, possibilitando adaptaçóes aos métodos antigos, aumentando consideravelmente a produtividade agrícola (ROSA et al., 2011).

O crescimento da produtividade agrícola implica consequentemente no aumento da geração dos resíduos deste mesmo setor, o que vêm se caracterizando como um progressivo problema nacional. Estima-se que em 2009 as geraçóes de resíduos oriundos das agroindústrias representaram em torno de 291 milhóes de toneladas (BRASIL, 2011). A geração de resíduos está diretamente relacionada com perdas entre produçấo e consumo, onde se estima que de 20,00 a $30,00 \%$ da safra de gráos, frutas e hortaliças sejam desperdiçadas entre a lavoura e o consumidor (ROSA et al., 2011).

Neste contexto, surge o conceito de biorrefinaria, que são instalaçôes e processos industriais que visam à transformação de biomassa lignocelulósica em produtos de alto valor agregado como: bioquímicos, biocombustíveis, bioenergia e biomateriais (SANTOS; COLODETTE; QUEIROZ, 2013). Pesquisas com cunho sustentável já são abundantes, voltadas especialmente para a utilização de resíduos agrícolas e florestais, pelo seu grande volume de geração (FAVARO, 2013). Os processos da biorrefinaria, apesar de bem estudados, ainda estáo em fase de aperfeiçoamento. Atualmente os processos da biorrefinaria se dividem em três categorias, de acordo com o tipo de processo usado para transformação: a) processos químicos, b) processos bioquímicos e c) processos termoquímicos (VAZ JÚNIOR, 2013).

Em um panorama global, a biorrefinaria já é muito estudada e incentivada, onde países mais de- senvolvidos trabalham para aumentar os processos de biorrefinaria e diversificar os insumos para criaçáo de novos produtos e processos (CHERUBINI, 2010). No Brasil, a biorrefinaria, apesar de ser conceitualmente nova, já se utiliza de vários processos, principalmente no setor sucroenergético e florestal (SANTOS, 2012; BASTOS, 2007).

Os produtos agrícola e florestal de maior impacto no Rio Grande do Sul (RS) são: arroz, soja, milho, eucalipto, tabaco e uva, que produzem, individualmente, uma quantidade significante de resíduos, o que poderia ser utilizado em processos de biorrefinaria. Dessa forma, o presente trabalho teve como objetivo fazer uma revisão do panorama das principais biomassas lignocelulósicas do estado do RS, e sua possível utilização em processos de biorrefinaria.

\section{BIOMASSA LIGNOCELULÓSICA}

A biomassa lignocelulósica é uma matéria-prima renovável com grande potencial de processamento para conversão em formas bioenergéticas mais elaboradas para o uso final (EICHLER et al., 2015). É um recurso natural, que em termos energéticos é toda e qualquer forma de energia acumulada através de processos fotossintéticos, sendo uma fonte promissora em biorrefinarias para produçáo de produtos de valor agregado devido a sua abundância, disponibilidade e caráter renovável (BANCO NACIONAL PARA O DESENVOLVIMENTO SOCIAL E ECONÔMICO; CENTRO DE GESTÃO E ESTUDOS ESTRATÉGICOS, 2008; SANTOS et al., 2013; PHITSUWAN; SAKKA; RATANAKHANOKCHAI, 2013, RAMBO; SCHMIDT; FERREIRA., 2015).

Dentre as fontes de biomassa que podem ser utilizadas em tais aplicaçóes têm-se culturas energéticas, resíduos agrícolas, resíduos florestais, resíduos industriais e urbanos (MAITY, 2015). As culturas energéticas geralmente são densamente plantadas, de alta produtividade e de curta duração como, por exemplo, bambu e trigo. Os resíduos agrícolas são compostos principalmente por caules e folhas que não são colhidos de plantaçóes comerciais, como casca de arroz, palha de cevada e palha de trigo. Já os resíduos florestais referem-se à biomassa náo colhida de locais de exploração madeireira, assim como biomassa resultante de operaçôes de manejo florestal. Os resíduos industriais e municipais incluem resíduos sólidos urbanos, lodo de esgoto e resíduos industriais (MAITY, 2015; SANTOS; COLODETTE; QUEIROZ, 
2013). Dessa forma, a utilizaçấo de biomassa dessas culturas para obtençáo de produtos é bastante vantajosa, uma vez que apresentam alta produtividade de biomassa, alto teor de carboidratos, são fáceis de cultivar com amplo cultivo em curto período tempo, são tolerantes à seca, a altas temperaturas, a enchentes e a estresse salino (PHITSUWAN; SAKKA; RATANAKHANOKCHAI, 2013).

A biomassa lignocelulósica é composta de três constituintes principais celulose, hemiceluloses e lignina, que formam uma estrutura de microfibrilas de celulose incorporadas em uma matriz de hemiceluloses e lignina. Além dos constituintes principais têm-se uma pequena quantidade de cinzas, que são os materiais inorgânicos, e extrativos, que são açúcares não estruturais, materiais nitrogenados, clorofila e ceras. A composição química da biomassa varia bastante de acordo com o tipo de planta, condições de cultivo e idade da planta como exposto na Tabela 1 (YANG; YU, 2013; SANTOS et al., 2012).

Tabela 1 - Composição química de diferentes tipos de biomassas lignocelulósicas.

\begin{tabular}{l|c|c|c}
\hline $\begin{array}{c}\text { Biomassa } \\
\text { Lignocelulósica }\end{array}$ & $\begin{array}{c}\% \\
\text { Celulose }\end{array}$ & $\begin{array}{c}\% \\
\text { Hemiceluloses }\end{array}$ & $\begin{array}{c}\% \\
\text { Lignina }\end{array}$ \\
\hline Bagaço de cana & 40 & 24 & 25 \\
\hline Palha de milho & 40 & 25 & 17 \\
\hline Sabugo de milho & 39 & 35 & 15 \\
\hline Fibra de milho & 15 & 35 & 8 \\
\hline Haste do algodão & 31 & 11 & 30 \\
\hline Palha de arroz & 35 & 25 & 12 \\
\hline Palha de soja & 25 & 12 & 18 \\
\hline Farelo de trigo & $10-15$ & $35-39$ & $8,3-12,5$ \\
\hline Palha de trigo & 38,2 & 21,2 & 23,4 \\
\hline Joio do trigo & 38 & 36 & 16 \\
\hline Gramíneas & $25-40$ & $35-50$ & $10-30$ \\
\hline $\begin{array}{l}\text { Madeira de lei } \\
\text { (álamo híbrido) }\end{array}$ & 44,7 & 18,6 & 26,4 \\
\hline $\begin{array}{l}\text { Madeira resinosa } \\
\text { (pinho) }\end{array}$ & 44,6 & 21,9 & 27,7 \\
\hline Resíduos de papel & 76 & 13 & 11 \\
\hline
\end{tabular}

Fonte: Yang e Yu (2013).

A celulose é o polímero natural de maior ocorrência natural no mundo (Figura 1). É um polímero de alto peso molecular $\left(10^{6} \mathrm{~kg} / \mathrm{mol}\right)$, linear, homogêneo, formado por unidades repetidas de $\beta$-celobiose, um dissacarídeo formado por duas moléculas de Dglicose, ligadas por ligações glicosídicas $\beta-1,4$. As uni- dades de glicose na $\beta$-celobiose estão invertidas em relação às moléculas vizinhas, levando à formação de uma cadeia glicana linear. As cadeias poliméricas lineares de celulose formam as microfibrilas que se ligam umas às outras por ligações de hidrogênio e interações de Van der Waals, conferindo uma alta resistência a ataques biológicos e alta cristalinidade. As características que conferem à celulose uma estrutura cristalina proporcionam elevada resistência à tensão, tornando a celulose insolúvel em água e em um grande número de outros solventes. Como as microfibrilas apresentam um comprimento longo, algumas regióes tornam-se desordenadas e amorfas. (SANTOS $e t$ al., 2012, PHITSUWAN; SAKKA; RATANAKHANOKCHAI, 2013, MABEE; MCFARLANE; SADDLER, 2011).

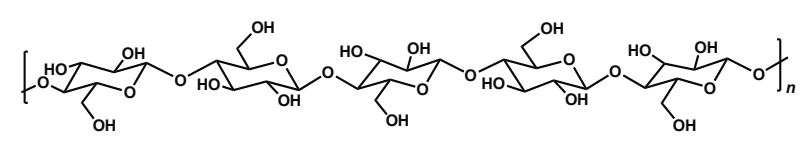

Fonte: Santos et al. (2012).

Figura 1 - Representação esquemática da molécula de celulose.

As hemiceluloses são heteropolissacarídeos complexos compostos por D-glicose, D-galactose, D-manose, D-xilose, L-arabinose, ácido D-glucurônico e ácido 4-O-metil-glucurônico (Figura 2). Esses polímeros são amorfos, ramificados e apresentam alguns substituintes de ácido acético e de ácidos urônicos, como os ácidos 4-O-metilglicurônicos, D-glicurônico e D-galacturônico. O bloco estrutural de hemiceluloses mais abundante em madeiras de lei e plantas agrícolas é a xilana, um polímero formado por unidades de xilose. Enquanto, em madeiras resinosas, o bloco estrutural mais abundante é a glucomana, um polímero com uma cadeia linear de D-manose e D-glicose conectadas por ligações glicosídicas $\beta-1,4$, e com algumas ramificaçōes. Alguns dos açúcares, presentes nas hemiceluloses, se associam a lignina, formando complexos carboidrato-lignina, tornando a clivagem enzimática de resíduos lignocelulósicos mais complicada (SANTOS et al., 2012; PHITSUWAN; SAKKA; RATANAKHANOKCHAI 2013; MAITY, 2015).

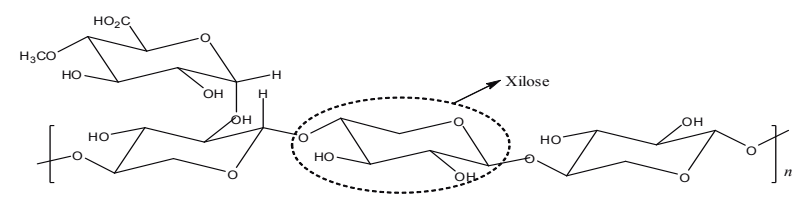

Fonte: Santos et al. (2012).

Figura 2 - Representação esquemática da molécula de hemiceluloses. 
A lignina é o polímero aromático de alto peso molecular mais abundante na natureza, sintetizado de precursores fenilpropanoides (Figura 3). É formado por diferentes unidades de fenilpropano: alcoóis coniferílico, sinapílico e cumarílico, conectados por diferentes tipos de ligaçôes. A composição e estrutura dos componentes da lignina não são uniformes e variam de acordo com o tipo de biomassa lignocelulósica em questão (SANTOS et al., 2012).

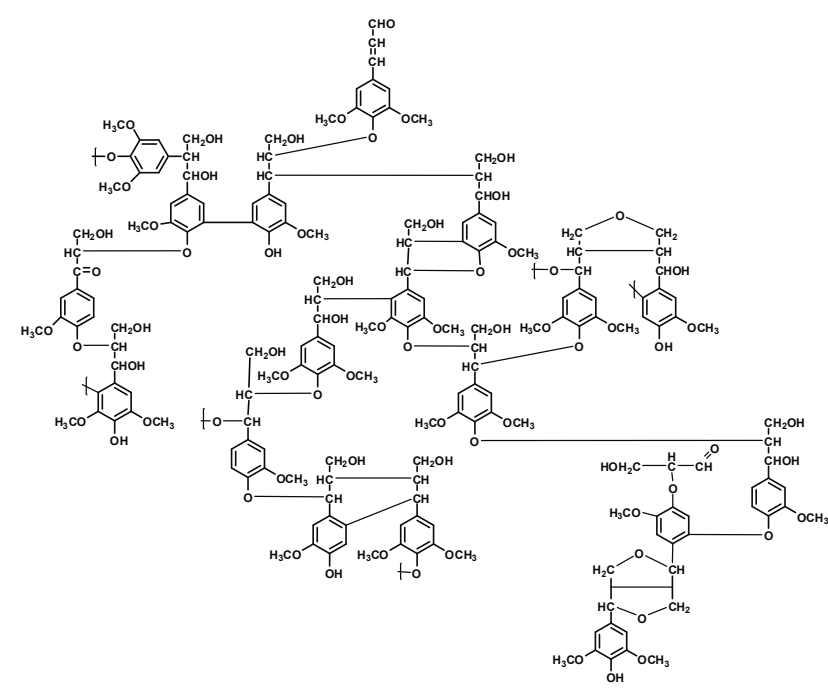

Fonte: Santos et al. (2012).

Figura 3 - Representação esquemática da molécula de lignina de eucalipto.

As interações intermoleculares entre os três principais componentes da biomassa lignocelulósica, celulose, hemiceluloses e lignina determinam a estrutura recalcitrante da biomassa. As ligaçóes de hidrogênio intramoleculares entre as hidroxilas conferem resistência à celulose tanto para hidrólise química e biológica. Além disso, o recobrimento das microfibrilas por lignina, hemiceluloses e regiōes amorfas da celulose também dificultam o acesso de enzimas catalíticas às microfibrilas. Dessa forma, a liberação dos polissacarídeos como fonte de açúcares fermentescíveis para produção de diferentes bioprodutos e formas energéticas é uma das etapas cruciais e limitantes da utilização da biomassa lignocelulósica, pois tem forte impacto em todas as outras etapas do processo. Devido à recalcitrância estrutural, a utilizaçáo de biomassa lignocelulósica necessita de uma etapa de pré-tratamento para seu eficiente fracionamento (SANTOS et al., 2013, 2014; YANG; YU, 2013; CORBETT et al., 2015; BUCKERIDGE; SANTOS; SOUZA, 2010).

\section{PROCESSOS NA BIORREFINARIA}

As rotas de biorrefinaria podem ser divididos de acordo com suas características e tipos de reações utilizadas, assim, são apresentados os 3 principais tipos de processos.

\subsection{Processos Químicos}

Processos químicos são exclusivamente baseados em reaçóes químicas de formação ou rompimento. No caso da biorrefinaria, a biomassa é primeiramente separada em fraçôes, como celulose, hemiceluloses e lignina, que podem ser usadas para o processamento químico. O tipo do processo químico usado depende da quantidade de substrato ou reagente recuperado da biomassa e também depende do produto final de interesse. Alguns exemplos de processos químicos são: Transesterificação Química; hidroprocessamento; craqueamento catalítico; reações de Fischer-Tropsch (VAZ JÚNIOR, 2013). Produtos como o biodiesel e gás sintético, que são biocombustíveis de alto valor agregado, podem ser obtidos através de processos químicos de biorrefinaria.

O biodiesel é definido como um combustível composto de ésteres monoalquila de longas cadeias de ácidos graxos derivados de óleos de origem vegetal ou renovável. Mais comumente, o biodiesel é obtido quimicamente através de uma técnica chama transesterificação. $\mathrm{Na}$ transesterificação, os triglicerídeos de origem vegetal reagem com algum álcool de cadeia curta, normalmente na presença de catalisador sobre elevada temperatura, produzindo o biodiesel e glicerol (TOMES, 2011). Três mols de biodiesel e um mol de glicerol são formados para cada mol de triglicerídeo que completa a conversão de transesterificação. Para este processo, diversos fatores influenciam a sua eficiência como: composição do óleo vegetal usado; álcool usado para reação; catalisador e temperatura usados para reação (TOMES, 2011). Desta forma, deve-se fazer uma prévia caracterização para avaliar o potencial de produção de biodiesel com o óleo vegetal usado (TOMES, 2011).

O processo Fischer-Tropsch foi idealizado em 1925, na Alemanha, e consiste na conversão de um gás sintético (syngas) composto de $\mathrm{H}_{2} \mathrm{e} \mathrm{CO}$ em hidrocarbonetos líquido. É o principal processo quando se pensa em tecnologias GTL, que se utilizam desse princípio das reaçôes de Fischer-Tropsch. Os produtos provenientes dos processos de Fischer-Tropsch variam muito, podendo obter desde óleos lubrificantes 
sintéticos até combustíveis e outros petroquímicos como metanol (SSCHULZ, 1999). Como a maioria das tecnologias na área da energia, esse processo derivou de um processamento de matéria prima de origem fóssil. Tipicamente o processo é feito com carvão ou gás natural e, só recentemente começaram-se processos industriais com gás sintético de biomassa\{Formatting Citation\} (TIJIMENSEN, 2002).

\subsection{Processos Bioquímicos}

Os processos bioquímicos são parecidos com os processos químicos no que se diz respeito às etapas de caracterização e pré-tratamento, onde é necessária uma análise prévia da biomassa para se pensar na melhor estratégia de obtenção do produto de interesse. Esses processos bioquímicos envolvem a utilização de microrganismos e enzimas, podendo ser em associação e até com uso de microrganismos recombinantes que expressam enzimas de outros organismos. Os exemplos mais comuns de processos bioquímicos são: Fermentação para obtenção de etanol e outros produtos químicos como ácidos orgânicos e outros álcoois; Digestão anaeróbica para produção de biogás e fertilizante; Transesterificação através de lípases para produção de biodiesel (VAZ JÚNIOR, 2013).

A tecnologia para obtenção de etanol de primeira geração através da fermentação já é bem consolidada e utilizada principalmente no Brasil que já é tido como referência mundial na produção do etanol de primeira geração. Já o processo de produção de etanol de segunda geração vem sendo amplamente estudada. Atualmente, as tecnologias envolvem o (1) pré-tratamento, que visa alterar ou remover a lignina e as hemiceluloses, aumentando a área superficial, e diminuir o grau de polimerização e cristalinidade da celulose; (2) a etapa de hidrólise, para obtenção dos açúcares fermentescíveis a partir da celulose e hemiceluloses; e (3) em seguida a conversão desses açúcares em etanol via fermentação e destilação (TOMES, 2011; SANTOS et al., 2013).

A produçấo de biogás tem sido muito estudada através da digestão anaeróbica de alguns microrganismos que conseguem degradar matéria orgânica, transformando em gás metano $\left(\mathrm{CH}_{4}\right)$, um gás com alto poder calorífico. A composição do biogás varia com a composição da biomassa utilizada para alimentação do processo, onde a composição normal do biogás consiste em $\mathrm{CH}_{4}(60,00-80,00 \%$ v/v) e dióxido de carbono $\left(\mathrm{CO}_{2}\right)(20,00-40,00 \% \mathrm{v} / \mathrm{v})$. O processo bio- químico pode ser dividido em quatro etapas: hidrólise, acidogênese, acetogênese e metanização. A etapa de hidrólise é realizada por microorganismos que sintetizam enzimas hidrolíticas como celulase, celobiase, xilanase, amilase, lípase e protease, que degradam polímeros e monômeros presentes na biomassa. $\mathrm{Na}$ etapa de acidogênese os monômeros obtidos são convertidos, através de microrganismos fermentativos, em gás hidrogênio $(\mathrm{H}), \mathrm{CO}_{2}$ e ácidos graxos voláteis como: ácido butanoico, ácido propanoico e ácido láctico. Em seguida, bactérias anaeróbicas como Acetobacterium woodii e Clostridium aceticum produzem, a partir dos produtos da acidogênese, ácido etanoico, hidrogênio e $\mathrm{CO}_{2}$. Por fim, bactérias metanogênicas como Methanosarcia barkeri e Metanonococcus mazei produzem $\mathrm{CH}_{4}$ a partir dos produtos anteriores (WEILAND, 2010).

\subsection{Processos Termoquímicos}

Da mesma forma que os demais processos, se faz necessário uma caracterização e pré-processamento da biomassa para melhor escolha e obtenção do produto de interesse. Os processos termoquímicos envolvem a utilização de calor para quebra e transformação dos compostos da biomassa, levando -os à combustão ou gaseificaçâa. Por meio da combustão, pode-se obter energia e alguns subprodutos no gás ou cinzas ao final do processo. A gaseificação é considerada a combustâo parcial do combustível, produzindo um gás sintético (syngas) com alto poder calorífico e potencial para produção de químicos (BASU, 2006). Outra possibilidade é a cogeração, onde se podem obter produtos como o gás sintético e, simultaneamente, obter energia através do calor liberado no processo (VAZ JÚNIOR, 2013). Os processos termoquímicos mais comuns são: combustấo para produção de energia; gaseificação para produção de gás sintético; pirólise para obtenção de bio-óleo e carvão vegetal e; cogeração para produção de produtos e energia.

O processo térmico mais comum de transformaçâo de biomassa em energia é a combustão direta. Quimicamente, o processo envolve a oxidaçáo total da matéria orgânica em $\mathrm{CO}_{2}$, água e outros gases em menor quantidade. Neste processo, é liberada uma grande quantidade de energia térmica, que pode ser recuperada para uso em outros processos na indústria ou pode ser usado para geração de energia através de vaporização de água e uso desse vapor em turbinas elétricas. Tipicamente, a composição da biomassa 
afeta a efetividade térmica do processo, onde maiores teores de carbono (C) e menores teores de umidade melhoram o rendimento térmico do processo. Outros fatores que influenciam a queima e recuperação de energia são: poder calorífico da madeira, densidade, teor de voláteis, teor de cinzas e granulometria do combustível (BASU, 2006).

A gaseificação é um processo que converte biomassa sólida em um gás sintético, composto, principalmente, de $\mathrm{H}$, monóxido de carbono $(\mathrm{CO})$ e $\mathrm{CO}_{2}$. O processo envolve uma combustáo parcial da matéria sólida em ambiente controlado para obter o gás sintético. A composição da biomassa utilizada afeta na composição final do gás obtido, mas geralmente, o produto obtido tem alto valor energético (LORA, 2012).

\section{BIOMASSAS LIGNOCELULÓSICAS NO RIO GRANDE DO SUL}

Dentre as diferentes biomassas cultivadas no estado do RS, algumas das principais e mais representantes na economia gaúcha são: eucalipto, tabaco, milho, uva, soja e arroz.

\subsection{Eucalipto}

O gênero Eucalyptus representa $76,60 \%$ do total de área de plantio florestal no Brasil, onde o crescimento de área em 2012 foi de 4,50\% em relação a 2011. De acordo com a Associação Brasileira de Produtores de Florestas Plantadas (2013), o principal fator envolvido nesse crescimento foi a futura demanda dos projetos industriais do setor de celulose e papel. Isso é previsível já que, de toda a área de plantio florestal de eucalipto, $72,50 \%$ é destinado ao segmento industrial de celulose e papel (ASSOCIAÇÃO BRASILEIRA DE PRODUTORES DE FLORESTAS PLANTADAS, 2013).

Atualmente o RS é um dos estados com maior área plantada de Eucalyptus no Brasil, com aproximadamente 0,28 milhóes de hectares de área plantada. Como pode ser visto na Figura 4, que apresenta a área plantada de Eucaliptus no RS e no Brasil, houve um crescimento considerável desde 2006 até 2012 na área plantada no cenário nacional, mas percebe-se que o aumento de área plantada no RS não foi correspondente ao aumento de área plantada no Brasil (ASSOCIAÇÃO BRASILEIRA DE PRODUTORES DE FLORESTAS PLANTADAS, 2013).

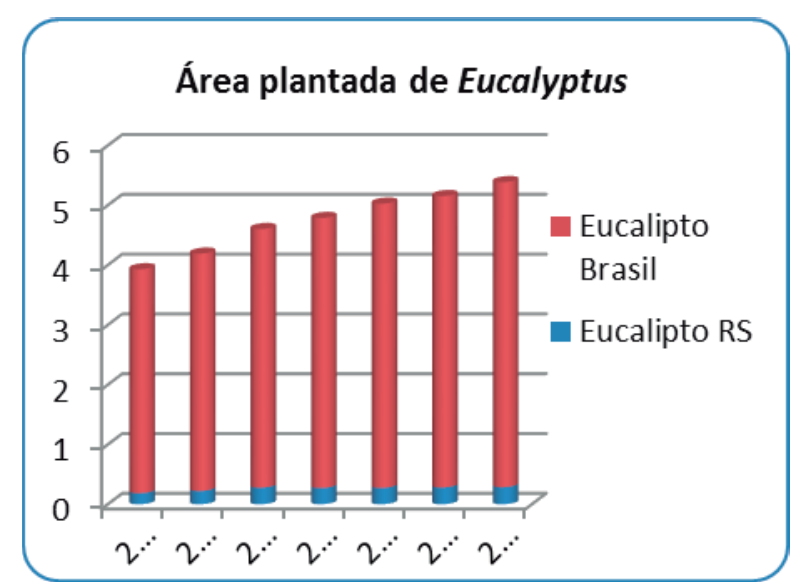

Fonte: Associação Brasileira de Produtores de Florestas Plantadas (2013).

Figura 4 - Área plantada de Eucalyptus no Rio Grande do Sul e no Brasil desde 2006 até 2012.

A composiçẫo básica da madeira de eucalipto é tida como aproximadamente $80,00 \%$ carbono fixo, $15,00 \%$ de teor de voláteis e $0,50 \%$ de cinzas, com Poder Calorífico da madeira em cerca de $4500 \mathrm{kcal} /$ kg (SANTOS; COLODETTE; QUEIROZ,, 2013). Essa composição imediata permite o estudo de processos de conversão térmica como pirólise, gaseificação e combustão, o que é interessante do ponto de vista econômico para esses processos termoquímicos (BASU, 2006).

Apesar de já obter grande importância nacional em processos energéticos, a biomassa de Eucalipto também é extremamente cogitada para outros processos de Biorrefinaria. Um forte exemplo é o uso da madeira para produção de celulose e papel, mercado que hoje é principal influência no plantio desse gênero no Brasil (ASSOCIAÇÃO BRASILEIRA DE PRODUTORES DE FLORESTAS PLANTADAS, 2013). Para este fim, análises de composição química são necessárias para avaliar o potencial de uso. Altos teores de celulose na madeira são favoráveis para produção de polpa destinada a papéis tipo tissue, enquanto teores de hemiceluloses elevados são favoráveis para a produção de polpa destinada à obtenção de papeis de imprimir e escrever (FERREIRA, 2006).

A lignina é um dos subprodutos gerado na indústria de papel e celulose, onde é principalmente usada para processos termoquímicos (recuperação de energia por queima) (SANTOS; COLODETTE; QUEIROZ,, 2013). Mas, outros produtos também podem ser obtidos a partir da purificação dessa lignina. Muitos trabalhos já estão usando lignina como composto para produção de polímeros e ligas poliméricas, empregando os diversos tipos de lignina (ligni- 
na Kraft, lignossulfonatos, lignina organosolv, hidrolítica) com foco para produtos de alto valor agregado (FELDMAN, 2002)

\subsection{Tabaco}

Nos últimos anos, com o intuito de eliminar a dependência de recursos fósseis como óleo, carvão e gás natural, serão eliminados em, respectivamente, 41, 64 e 155 anos. E com aumento do crescimento populacional, assim como o aumento de resíduos e de consumo de derivados do petróleo, muito países estão investindo em alternativas sustentáveis a partir da biomassa, como bioenergia e bioprodutos.

Visando a necessidade de diversificação de culturas, o uso da biomassa lignocelulósica tem se mostrado atraente. O tabaco é produzido em mais de 119 países (USTA, 2005a), sua produção mundial na última década variou entre 6-6.8 milhóes de toneladas (PARANÁ, 2012). O Brasil é o segundo maior produtor e a produção do RS junto com Santa Catarina e Paraná somam 735 toneladas produzidas na safra 2013/2014 (ASSOCIAÇÃO DOS FUMICULTORES DO BRASIL, 2013). Ainda, o óleo gerado a partir das sementes do tabaco pode ser considerado um substituto renovável ao óleo diesel (USTA 2005a; USTA 2005b; GIANNELOS et al., 2002).

Segundo Usta (2005a), as sementes contêm uma quantidade significativa de óleo, variando entre 36,00$41,00 \%$ do peso usando éster metílico. Conforme

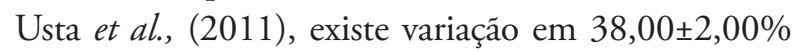
usando éster dietílico como solvente extrativo. Além disso, o biodiesel originado da semente do tabaco pode auxiliar na redução de emissôes como $\mathrm{CO}$ e dióxido de enxofre $\left(\mathrm{SO}_{2}\right)$ (com uma pequena contribuiçáo na liberaçáo de emissóes de NOx).

O cultivo de tabaco no Brasil tem como base os pequenos agricultores, propriedades possuem em média 15,20 hectares, sendo que destes, apenas 16,60\% são dedicados à produção, o cultivo representa $47,90 \%$ da renda familiar dos agricultores (SINDICATO INTERESTADUAL DA INDÚSTRIA DO TABACO, [2016?]). Geralmente, as sementes de tabaco são desprezadas no Brasil, país que produz grande quantidade por safra. Apenas uma pequena parte é salva para o plantio da nova safra. Segundo a Associação dos Fumicultores do Brasil (2013), o tabaco energético, variedade com maior quantidade de sementes, tem sido experimentado na região de Rio Pardo/RS. As vantagens apresentadas seriam: a conveniência do aproveitamento dos métodos de plantio já utilizados pelos pequenos agricultores, os quais totalizam 84 mil produtores e 337 mil pessoas envolvidas no meio rural; alternativa sustentável, pois $100 \%$ da planta seriam aproveitadas para biodiesel, ração e biomassa, além de ser uma alternativa para diversificação rural, a qual já é incentivada há décadas pelo setor como forma de complementar a renda dos produtores (SINDICATO INTERESTADUAL DA INDÚSTRIA DO TABACO, [2016?).

\subsection{Milho}

Dentre todos os cereais cultivados no Brasil, temos o milho com cerca de 54,37 milhóes de toneladas de grãos produzidos, em uma área de aproximadamente 12,93 milhóes de hectares (COMPANHIA NACIONAL DE ABASTECIMENTO, 20101a apud EMPRESA NACIONAL DE PESQUISA AGROPECUÁRIA, 2010 ). Por suas características fisiológicas, a cultura do milho tem alto potencial produtivo, já tendo sido obtida no Brasil produtividade superior a 16,00 t/ha. No entanto, o nível médio nacional de produtividade é muito baixo, cerca de 4417 $\mathrm{kg} / \mathrm{ha}$ na primeira e segunda safra, demonstrando que os diferentes sistemas de produção de milho deverão ser ainda bastante aprimorados para se obter aumento na produtividade e na rentabilidade que a cultura pode proporcionar (EMPRESA BRASILEIRA DE PESQUISA AGROPECUÁRIA, 2010).

A América é responsável por cerca de 52,00\% de todo o milho produzido mundialmente (UNITED STATES, 2016). Entre os países do continente americano, o Brasil é o terceiro maior produtor mundial de milho, produzindo aproximadamente $6,50 \%$ do total produzido no mundo, é superado pelos Estados Unidos com $37,00 \%$ e pela China com $21,00 \%$ da produção total.

Nesse contexto, no mês de janeiro, o RS apontou aumento de $1,10 \%$ de ganhos de produçáo e 1,40\% de rendimento médio na primeira safra. A estimativa para a produção nacional de milho na segunda safra em 2014 é de 42,20 milhóes de toneladas, 0,50\% superior à estimativa de fevereiro. A área total plantada ou a plantar com a cultura é de 8.650 .834 hectares, $2,70 \%$ superior ao mês anterior. E em fevereiro, o $\mathrm{RS}$, atual primeiro maior produtor de milho primeira safra, segue com colheitas dentro da normalidade. $\mathrm{O}$ estado conta com bom rendimento médio, $6347 \mathrm{~kg} /$ ha com produção estimada de 5,50 milhóes de tone-

\footnotetext{
${ }^{1}$ Companhia Nacional de Abastecimento, 2010.
} 
ladas, 2,30\% maior que avaliada no mês anterior e área plantada estimada com leve retraçáo de $0,20 \%$, ficando em 867270 hectares devido à chuva e alteraçôes de clima inesperado (INSTITUTO BRASILEIRO DE GEOGRAFIA E ESTATÍSTICA, [2015?a]).

Houve uma grande evolução das culturas no Noroeste e no Centro-Ocidental Rio-Grandense no período de outubro/2014 a abril/2015, tais mesorregiôes são as mais representativas na produção de soja e milho no estado. E, tiveram comportamentos parecidos na safra 2014/15 e também nas safras anteriores, com aumento da safra nesse período. Porém, apresentou uma queda acentuada a partir de março/15 que foi atípica para esta época do ano e pode ter sido em decorrência de precipitaçôes reduzidas. Tais condiçôes implicaram uma maturação e colheitas mais cedo, entretanto não houve prejuízo considerável de rendimento da safra de grãos 2014/15 (COMPANHIA NACIONAL DE ABASTECIMENTO, 2015).

Tais produçóes acarretam viabilidade econômica para o país, mas, os resíduos agroindustriais são gerados desde o processamento dos grãos, como nas diversas fases de fabricação e beneficiamento, o que gera uma grande quantidade de resíduos gerados. Esses resíduos, além de criar potenciais problemas ambientais, como poluição do solo, poluição das águas superficiais e subterrâneas, representam perdas de matérias-primas e energia, exigindo investimentos significativos em tratamentos para controlar a poluição. Muitos dos tratamentos não eliminam realmente os resíduos gerados, apenas os transferem de um meio ao outro (TIMOFIECSYK; PAWLOWSKY, 2000).

O milho constitui a base energética da dieta de várias espécies animais, é composto de amido (60,00\%), casca $(6,50 \%)$, glúten $(10,00 \%)$, gérmen $(8,50 \%)$ e água $(15,00 \%)$ (BARBOSA, 2004). Segundo Weber (2005), em vários locais do mundo o milho é tido como o produto mais importante na dieta alimentar humana e utilizado como matéria prima para a alimentação animal. Com base nos grãos secos a composição do milho é de aproximadamente $77,00 \%$ de amido, 2,00\% de açúcar, 9,00\% de proteínas, 5,00\% de azeite; $5,00 \%$ de pentosanas, $2,00 \%$ de cinza, contém ainda, mínimas quantidades de sais de cálcio, magnésio, fósforo, alumínio, ferro, sódio, potássio e cloro.

Algumas partes da planta do milho não podem ser usadas diretamente, e neste caso, são subutilizadas. No sabugo a parte central da espiga, na qual os grãos estão presos, é o resíduo gerado após ser derrubado o milho. Para cada $100 \mathrm{~kg}$ de espigas de milho, aproximadamente $18 \mathrm{~kg}(70,00 \%$ base úmida), são formados pelo sabugo que podem servir de base para ração de ruminantes (BASTOS et al., 2007).

Estruturalmente, o sabugo é formado por quatro partes distintas: palha fina, palha grossa, anel lenhoso, e medula. A palha fina constitui aproximadamente $4,10 \%$ do sabugo do milho em peso, a palha grossa $33,70 \%$, o anel lenhoso $60,30 \%$ e a medula $1,90 \%$. Devido às características de dureza e resistência à abrasão, os componentes do sabugo serviram de base ao início de suas aplicações na indústria. $\mathrm{O}$ pH da superfície granular do sabugo é 7,4, e no seu interior 4,9. Estes valores contribuem para que o sabugo funcione como suporte inerte para vários materiais (BASTOS et al., 2007).

A palha de milho pode ser utilizada na biorrefinaria para produção de biocombustíveis. Devido à oferta limitada de combustíveis fósseis, tem havido um maior interesse e maior esforço para a produçáo de biocombustíveis através de fermentaçáo da biomassa lignocelulósica. (DEMIRBAS, 2008; GALBE; ZACCHI, 2007).

Nos últimos anos, surgiu o biobutanol como um substituto direto da gasolina ou como um aditivo de combustível. Comparado com o etanol, o butanol é atraente para aplicação como um biocombustível devido a suas características químicas e físicas superiores, tais como uma maior densidade de energia $(29,2$ $\mathrm{MJ} / \mathrm{L}$ ), menor viscosidade, menor tendência para absorver água e menos corrosivo para determinadas peças do motor (NI; WANG; SUN, 2012).

Assim, resíduos do milho, que são utilizados para fins de produção de biocombustíveis, como o bioetanol, são eficientes na alta cultura $(8,00 \mathrm{t} / \mathrm{ha})$ e rendimento $(417 \mathrm{~L} / \mathrm{t})$ por hectare. $\mathrm{O}$ crescimento em longo prazo é um dos maiores obstáculos para a utilizaçáo de milho como uma matéria-prima, pois afetam o surgimento de híbridos, porém, isso permite o estudo de diferentes espécies e suas características e propriedades na produção de biocombustíveis (RAMCHANDRAN et al., 2015).

\subsection{Uva}

O desenvolvimento da ciência e da tecnologia nas últimas décadas tiveram efeitos consideráveis sobre o aumento da produçáo e produtividade da maioria das culturas, como a uva (BRASIL, [2016?]).

Dessa forma, as uvas estão economicamente entre os frutos mais importantes no mundo, existem de 8.000 a 10.000 cultivares de videira existentes em 
todo o mundo hoje (RAMEZANI et al., 2009), e a maioria das cultivares de produçáo são derivados de uma única espécie de $V$. vinifera, devido à sua elevada gama de qualidades. No entanto, $V$. vinifera é altamente susceptível a doenças fúngicas, o que causa grandes perdas na produção de uva (WAN et al., 2008).

A Serra Gaúcha, a mais importante região vinícola brasileira, também foi influenciada por esse desenvolvimento científico e tecnológico com o uso de diferentes insumos agrícolas - tais como fungicidas, inseticidas, herbicidas, reguladores de crescimento, fertilizantes e também pelo uso de enzimas, estabilizadores e antioxidantes (MIELE et al, 2015).

A vitivinicultura ocupa uma extensa área de 81 mil hectares, dentre os quais duas regiôes se destacam: RS que contribui com 777 milhóes de quilos de uva por ano e, além disso, possui a maior produção de vinhos e derivados da uva (BRASIL, [2016?]) .

A produção de uva no Brasil pode ser analisada através das áreas de cultivo da fruta e da colheita da uva conforme Tabela 2.

Tabela 2 - Áreas plantada e colhida de uva em setembro de 2014 e 2015.

\begin{tabular}{c|c|c|c}
\hline $\begin{array}{c}\text { Brasil e as } \\
\text { Unidades da } \\
\text { Federaçáo }\end{array}$ & $\begin{array}{c}\text { Ano da } \\
\text { Safra }\end{array}$ & $\begin{array}{c}\text { Área } \\
\text { Plantada } \\
\text { (Hectares) }\end{array}$ & $\begin{array}{c}\text { Área } \\
\text { Colhida } \\
\text { (Hectares) }\end{array}$ \\
\hline \multirow{2}{*}{ Brasil } & Safra 2014 & 80548 & 79168 \\
\cline { 2 - 4 } & Safra 2015 & 79562 & 78222 \\
\hline \multirow{2}{*}{$\begin{array}{c}\text { Rio Grande } \\
\text { do Sul }\end{array}$} & Safra 2014 & 51005 & 49998 \\
\cline { 2 - 4 } & Safra 2015 & 50743 & 49737 \\
\hline
\end{tabular}

Fonte: Adaptado de Instituto Brasileiro de Geografia e Estatísitica (2015).

Verificamos que as áreas plantada e colhida de uvas no Brasil em setembro apresentou uma queda nacional de área plantada em torno de $1,30 \%$ e área colhida 1,20\% quando comparado ao mesmo mês de 2014. A maior parte da produção de uva do país advém do Estado do RS, com área plantada em torno de 50743 ha e área colhida de aproximadamente 49737 ha, porém, devido ao grande índice de chuvas no mês de setembro de 2015, a área colhida sofreu uma leve queda em relação a 2014 (INSTITUTO BRASILEIRO DE GEOGRAFIA E ESTATÍSTICA, [2015?]b).

A uva, na sua grande maioria, é apreciada para consumo in natura, mas também é utilizada na fabricação de diversos produtos, como suco, doces, vinho e vinagre. Além disso, subprodutos como corantes naturais, ácido tartárico, óleo de semente e taninos. A produção de vinhos, suco de uva e derivados está concentrada no RS, onde são fabricados cerca de 300 milhões de litros de vinho e mosto, representando $95,00 \%$ da produção brasileira (SERVIÇO BRASILEIRO DE APOIO ÀS MICRO E PEQUENAS EMPRESAS, 2016).

A uva é composta por taninos, lignina, celulose e hemiceluloses principalmente, dentre essas substâncias estão os açúcares, principalmente glicose e frutose que são fermentáveis para produção de álcool. A modernização e utilização de seus componentes e resíduos podem acarretar melhorias econômicas e ambientais (PING, et al., 2011).

O bagaço, nome genérico dado ao principal resíduo gerado no processo de vinificaçáo, é tipicamente uma mistura heterogênea composta por $50,00 \%$ de peles de uva e restos de polpa (folhelho), $25,00 \%$ sementes (grainhas) e $25,00 \%$ de caules (engaço). Do ponto de vista químico, este subproduto é rico em alcoóis, ácidos, aldeídos, ésteres, pectinas, polifenóis, minerais, açúcares e fibras, apresentando por isso um elevado potencial de valorização (RUBERTO et al., 2008).

As grainhas ou sementes são constituídas por uma estrutura externa rica em celulose $(30,00 \%$ da massa total) que protege o embrião no seu interior e que contém entre 15,00 a $20,00 \%$ de óleos com elevada concentração de lípidos polissaturados (ácido linoleico). Adicionalmente, os níveis de taninos condensados impregnados na celulose e/ou dispersos no interior também é significativo, podendo atingir 10,00\% da massa da grainha. $\mathrm{O}$ engaço é essencialmente um material lenho-celulósico contendo cerca de 15,00\% de taninos. O folhelho, que representa cerca de 50,00\% da massa fresca do engaço da uva, é essencialmente constituído por polissacarídeos estruturais (celulose e hemiceluloses), proteínas, taninos, açúcares (principalmente glicose e frutose), lipídios (ácidos gordos, ceras) e minerais (MENDES et al., 2013).

Os taninos poderão ser valorizados como corantes naturais, antioxidantes e na preparação de adesivos para substituir as atuais resinas de ureia/formaldeído e fenol/formaldeído. Os açúcares solúveis e os extratos sólidos obtidos, ricos em celulose e hemiceluloses passarão para plataforma biotecnológica. As hemiceluloses (principalmente pectinas e glucomananas) e outros açúcares solúveis em água são facilmente utilizados na produção de bioetanol (OCTAVE; THOMAS, 2009).

Nesse contexto, resíduos da uva são muito utilizados para produção de biocombustíveis de alto valor como o bioetanol e biodiesel, o óleo proveniente da uva é utilizado nas reaçôes químicas envolvidas, de 
forma que da semente da uva o biodiesel é obtido. Já o bioetanol, é obtido a partir da fermentaçáo de subprodutos - bagaços e borras (RAMOS et al., 2009).

Assim, os produtos e subprodutos advindos da utilização da uva apresentam grande potencial para reuso de seus componentes. A biomassa residual implica em grande potencial para produção de biocombustíveis e extração de substâncias como compostos fenólicos para utilização industrial. Logo, sua utilização nas indústrias e na sociedade, de forma geral, acarreta na diminuição de gastos e reuso de matéria orgânica que seria descartada (FLOUROS et al., 2003).

\subsection{Soja}

A soja, complexo que compreende grãos, farelo e óleo, é uma das commodities com maiores perspectivas de revolucionar o mercado dos alimentos funcionais no Brasil e no mundo, e podem divergir com relação à sua habilidade competitiva (ASSOCIAÇÁO DOS PRODUTORES DE SOJA DO BRASIL, [2014?]). A soja (Glycine max) é explorada no oriente há cerca de cinco mil anos, resultada do cruzamento de duas espécies de soja selvagem, que foram domesticadas e melhoradas por pesquisadores da antiga China (ASSOCIAÇÃO DOS PRODUTORES DE SOJA DO BRASIL, [2014?]).. Diferente dos ancestrais que lhe deram origem, esta era cultivada como um grâo sagrado pela civilização chinesa devido a sua importância na dieta alimentar (ASSOCIAÇÁO DOS PRODUTORES DE SOJA DO BRASIL, [2014?])..

Em 1891, a soja era estudada no Brasil como cultura forrageira, fortuitamente também eram produzidos grãos para consumo de animais agrícolas. Em 1900 e 1901, ocorreu à primeira distribuição de sementes de soja para produtores paulistas, e no mesmo período, registrou o primeiro cultivo no RS, onde a cultura encontrou condições climáticas semelhantes ao ecossistema de origem, sul dos EUA. Em 1914, foi no município de Santa Maria/RS que ocorreu o primeiro registro de soja cultivada no brasil. No entanto, foi a partir da década de 1960 , o cultivo foi impulsionado pelas políticas subsidiárias planejando sua autossuficiência, consequentemente, a soja se estabeleceu como uma cultura importante no Brasil (ASSOCIAÇÃO DOS PRODUTORES DE SOJA DO BRASIL, [2014?]).

Dentre as culturas de grãos, a soja é a mais promissora do país. Sua produção se consolidou no Brasil na década de 70 , passando de 1,50 milhôes de toneladas para 15 milhóes, devido ao aumento da área de produção e progresso na produtividade, onde mais de $80 \%$ do volume produzido se concentrava nos três estados da regiáo sul do país (ASSOCIAÇÃO DOS PRODUTORES DE SOJA DO BRASIL, [2014?]).. No RS, os principais municípios produtores encontram-se principalmente na porção norte/noroeste do estado. No período 2009 a 2011, houve produção média superior a 100000 toneladas/ ano em 18 municípios, ainda, dentre estes, deve-se destacar Cruz Alta, Palmeira das Missóes e Tupanciretã, onde a produção média variou de 211574 toneladas a 367650 toneladas (SECRETARIA DE PLANEJAMENTO, MOBILIDADE E DESENVOLVIMENTO REGIONAL, 2011). Segundo Feix e Leusin Júnior (2015), as exportaçóes do agronegócio gaúcho somaram 12,20 bilhóes de dólares em 2014, dos quais $44,10 \%$ são representado pelo complexo soja (grão, farelo e óleo).

Na safra 2015/2016, as estimativas no Brasil que para a cultura da soja são: 32 milhóes de hectares de área plantada - grãos, 96 milhóes de toneladas de produção no verão e $3000 \mathrm{~kg} / \mathrm{ha}$ de produtividade. No RS, a área cultivada com soja deverá crescer entre 1,00 e 2,50\% em áreas semeadas anteriormente com milho, área de campos nativos e pastagens, ainda a previsão é de que alcancem 5340 mil hectares até o final da safra 2016. Ainda, a produtividade da região sul obteve o segundo maior incremento na produtividade, atingindo $3076 \mathrm{~kg} / \mathrm{ha}$ (COMPANHIA NACIONAL DE ABASTECIMENTO, 2016) Segundo a Companhia Nacional de Abastecimento ([2016?]), foram 5216 milhôes de hectares de área plantada, 14688 milhóes de toneladas de produção e $2816 \mathrm{~kg} /$ ha de produtividade na safra 2014/2015 do RS.

A gestão inadequada dos resíduos acaba acarretando a degradação do solo, assim como a sua contaminação. O estudo abordado por Pukasiewicz, Oliveira e Pilatti (2004), apresentou que $84,48 \%$ do total dos resíduos sólidos gerados na soja é casca da soja, e $0,04 \%$ seria a borra do óleo, $0,03 \%$ seria resíduo orgânico gerado no processamento, $5,82 \%$ seriam as cinzas geradas pós-processamento.

Sementes de soja descascadas contêm uma média de $41,00 \%$ de proteína, $28,00 \%$ sendo de hidratos de carbono, $25,00 \%$ de óleo e $5,00 \%$ de cinzas (DAVEBY; AMAN, 1993). De acordo com os resultados da composição centesimal, o resíduo de soja possui uma boa qualidade químico-nutricional, sendo $33,00 \%$ fonte de carboidratos, $47,00 \%$ proteínas, $5,00 \%$ cinzas e 5,00\% fibra bruta (SILVA et al., 2006). 


\subsection{Arroz}

$\mathrm{O}$ arroz é um dos produtos destinados à alimentaçẫo humana de maior importância, sendo um dos cereais mais consumidos no mundo. O Brasil está entre os dez maiores produtores de arroz mundiais, apresentado dois sistemas de cultivo, o do grão irrigado e de sequeiro. Com relação ao consumo de arroz, estima-se uma demanda de 12 milhóes de toneladas do grão no país por ano. O cultivo irrigado é responsável por $65,00 \%$ da produção nacional, sendo que a Regiâo Sul é responsável por mais da metade da produção de arroz irrigado no país. (EMBRAPA CLIMA TEMPERADO, 2005; COMPANHIA NACIONAL DE ABASTECIMENTO, 2014)

Houve um crescimento na cultura orizícola no Brasil de 21,86\% entre as safras de 1990/91 e 2012/13, obtida a partir do aumento da produtividade no setor. O RS foi o maior responsável pelo expressivo crescimento na produçáo, que nesse período aumentou em $88,97 \%$ a sua produção, sendo responsável por $2 / 3$ da produçáo nacional de arroz. Na Figura 5 é mostrado o crescimento da orizicultura no Brasil entre as safras de 1990/91 e 2012/13, enquanto na Figura 6, é mostrada a evolução da produção e produtividade do arroz no RS num período de quase cem anos (COMPANHIA NACIONAL DE ABASTECIMENTO, 2014).

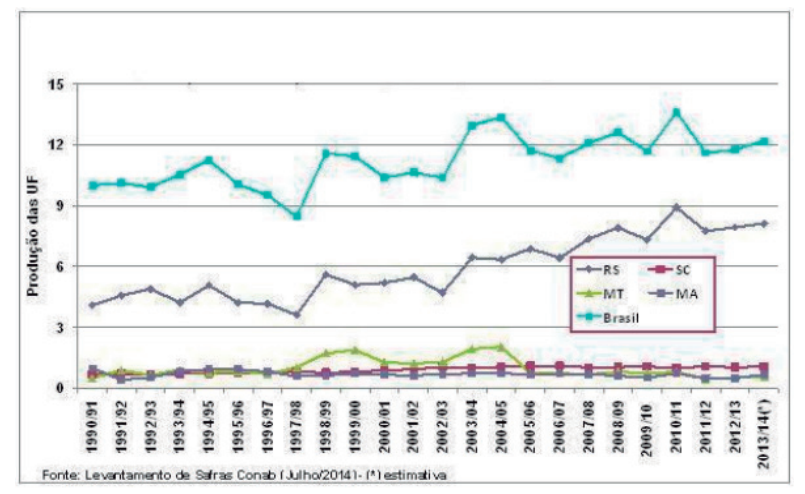

Fonte: Companhia Nacional de Abastecimento (2014).

Figura 5 - Crescimento da produção de arroz no Brasil.

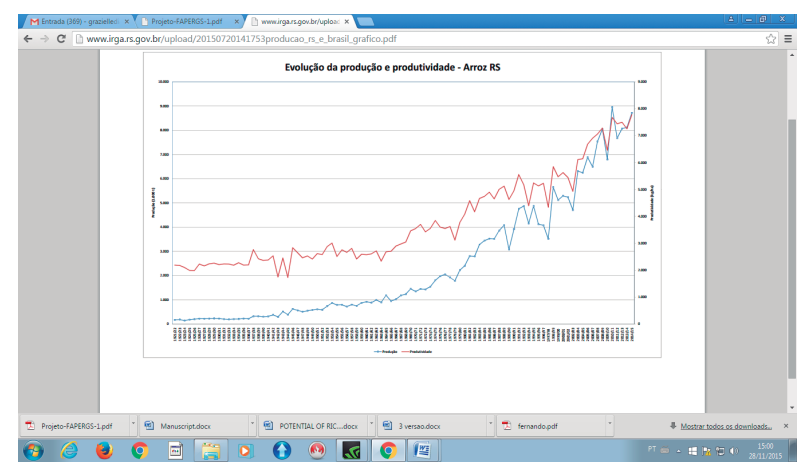

Fonte: Instituto Riograndense do Arroz ([2015?]).

Figura 6 - Crescimento da produçáo e produtividade do arroz no RS.
Desde o cultivo do arroz até o seu processamento na indústria uma grande quantidade de resíduos é gerada, dentre os quais se destacam a casca e a palha do arroz, com cerca de $125,00 \%(\mathrm{~kg} / \mathrm{kg})$ e $25 \%(\mathrm{~kg} / \mathrm{kg})$, respectivamente, em relação ao grão de arroz descascado e não polido (RODRIGUES et al., 2012).

A casca de arroz corresponde a aproximadamente $20 \%$ do peso seco do grão, levando a produção de milhôes de toneladas por anos. É um material de difícil degradação que ocupa grandes volumes em aterros sanitários quando disposto como resíduo. Atualmente, a maior utilizaçáo da casca de arroz é na produção de energia a partir da sua queima, sendo interessante a busca de novas formas de sua utilização que agreguem maior valor ao produto final (MENEZES et al., 2008). A palha de arroz gerada durante o beneficiamento do grão é utilizada em parte para produção de ração animal, e o restante é tratado como resíduo (LIU et al., 2014).

Com relação à composição química desses resíduos, a casca de arroz é composta de aproximadamente $35,00 \%$ de celulose, $25,00 \%$ de hemiceluloses, $20,00 \%$ de lignina e $20,00 \%$ de sílica (ZHANG et al., 2015). Já a palha de arroz é composta por aproximadamente $37,00 \%$ de celulose, $24,00 \%$ de hemiceluloses e $14,00 \%$ de lignina (RANJAN; MOHOLKAR, 2013). Ambos resíduos podem ser usados como matéria-prima para conversão em produtos de alto valor agregado como biocombustíveis, bioenergia, biomateriais e bioquímicos (SANTOS et al., 2013; VAZ JÚNIOR, 2013; CHEALI et al., 2015; YANG e YU, 2013).

Vários estudos têm sido conduzidos visando à conversão dos resíduos da produção de arroz em produtos de alto valor agregado. A produçáo simultânea de acetona, butanol e etanol empregando diferentes pré-tratamentos como explosão a vapor, tratamento ácido, tratamento ácido seguido de tratamento enzimático e tratamento organosolv já foram investigados utilizando a palha de arroz como matéria-prima e o efeito de cada pré-tratamento na produtividade analisado. Quando se empregando tratamento ácido seguido de tratamento enzimático, obtém-se maior liberação de glicose, já quando se utiliza o tratamento organosolv tem-se um aumento na produtividade de butanol, etanol e acetona, visto que a lignina é removida nesse tipo de tratamento impedindo a formação de potenciais inibidores da fermentação (RANJAN; MOHOLKAR, 2013; AMIRI; KARIMI; ZILOUEI, 2014). 
A utilização de palha de arroz para produção de etanol já foi investigada, analisando-se os efeitos da esterilização do material antes da fermentação. Foi observado que quando o material não foi previamente esterilizado, uma menor produção de etanol foi obtida e maior produção de ácido lático foi observada, indicando que a fermentação lática continuou a acontecer juntamente com a fermentação alcoólica. Desse modo a palha de arroz ensilada pode ser considerada uma possível matéria-prima para produção de ácido lático (SHINOZAKI et al., 2011)

O ácido levulínico, assim como o etanol, é um químico que pode ser convertido em vários outros produtos. Devido à presença de um grupo cetona e um grupo carboxílico, esse ácido é um bloco versátil para produçáo de aditivos de combustíveis, precursores de polímeros e resinas. De acordo com Hongzhang, Bin, e Shengying (2011) que estudaram a produção de ácido levulínico a partir da palha de arroz, após pré-tratamento de explosão a vapor e utilizando catalisador superácido sólido obtendo produtividade de 70,00\%. A produção de outros produtos tais como biohidrogênico - para utilizaçấo como biocombustível; celulases, hemicelulases, lacases - para hidrólise de celulose, hemiceluloses e lignina respectivamente; xilitol - agente adoçante; furfural - produção de fármacos, pesticidas e aditivos, entre outros produtos de alto valor agregado vem sendo investigada a partir da casca e palha de arroz, estudando o potencial de utilização desses resíduos e buscando aprimorar os processos para obter maior produtividade (HE et al., 2014, HIDENO et al., 2011; OKAMOTO et al., 2011; SOUSA-AGUIAR et al., 2014; LIN; HUANG; CHANG, 2013).

Desta forma, existem diversas possibilidades de uso da biorrefinaria que apontam para um enorme potencial econômico no Brasil, país que possui grande deficiência tecnológica em setores químicos e afins. Cria-se, portanto, uma nova mescla entre a tecnologia e a economia para o agronegócio (COMPANHIA NACIONAL DE ABASTECIMENTO, 2014).

\section{CONSIDERAÇÓES FINAIS}

Levando em consideraçáo todas as diferentes biomassas lignocelulósicas discutidas e as possíveis aplicaçóes de seus resíduos em diferentes processos industriais, observamos que o RS apresenta um grande potencial na reutilização de tais resíduos na implementação industrial, de forma a viabilizar economicamente e ambientalmente os processos industriais.
As culturas apresentadas possuem componentes que podem ser utilizados em diferentes processos de biorrefinaria, tais como químicos, bioquímicos e térmicos. Além disso, os resíduos ricos em componentes reutilizáveis, que geralmente são descartados ou utilizados de forma menos nobre, proporcionariam sustentabilidade em diferentes processos industriais no RS. Assim, tais culturas vêm sendo estudadas devido ao alto potencial químico e energético, com intuito de serem reutilizados da forma mais viável e sustentável possível.

\section{AGRADECIMENTOS}

Os agradecimentos se direcionam ao Grupo de Pesquisa - Centro de Estudos em Biorrefinaria. E, também a FAPERGS, CNPq e UERGS que confiaram no trabalho de forma a contribuir com investimentos direcionados à pesquisa e conhecimento científico.

\section{REFERÊNCIAS}

ASSOCIAÇÃO BRASILEIRA DE PRODUTORES DE FLORESTAS PLANTADAS. Anuário Estatístico 2013: Ano base 2012. Brasília: ABRAF, 2013.

ASSOCIAÇÃO DOS FUMICULTORES DO BRASIL. Tabaco energético pode servir a produçáo de biocombustiveis no RS. 2013. Disponível em: <www.afubra.com. br>. Acesso em: 23 nov. 2015.

AMIRI, H., KARIMI, K., ZILOUEI, H. Organosolv pretreatment of rice straw for efficient acetone, butanol, and ethanol production. Bioresource Technology, v. 152, p. 450-456, 2014.

ASSOCIAÇÃO DOS PRODUTORES DE SOJA DO BRASIL. A História da soja. [2014?]. Disponível em: < http://aprosojabrasil.com.br/2014/sobre-a-soja/a-historiada-soja/ > Acesso em: 24 nov. 2015

BANCO NACIONAL PARA O DESENVOLVIMENTO SOCIAL E ECONÔMICO; CENTRO DE GESTÃO E ESTUdOS ESTRATÉGICOS. Bioetanol de cana-de-açúcar: Energia para o desenvolvimento sustentável. Rio de Janeiro: BNDES; CGEE, 2008. 316p.

BARBOSA, F. A. Alimentos na Nutriçáo de Bovinos. Salvador: UFBA, 2004 Disponível em <www.agronomia. com.br/conteudo/artigos>. Acesso em: 23 nov. 2015.

BASTOS, R. et al. Elaboração de Páes com Adição de Farinha de Sabugo de Milho. Revista Ciências Exatas e Na- 
turais, v. 9, n. 1, jan./jun., 2007.

BASTOS, V. D. Etanol, Alcoolquímica e Biorrefinarias. BNDES setorial, Rio de Janeiro, n. 25, p. 5-38. mar. 2007.

BASU, P. Combustion and Gasification in Fluidized Beds. CRC Press, 2006.

BRASIL. Ministério da Agricultura. Cultura de uva. [2016?]. Disponível em: <http://www.agricultura.gov.br/ vegetal/culturas/uva>. Acesso em: 06 out. 2015.

BRASIL. Ministério do Meio Ambiente. Plano Nacional de Resíduos Sólidos. Brasília: MMA, 2011.

BUCKERIDGE, M.S.; SANTOS, W.D.; SOUZA, A.P. As rotas para o etanol celulósico no Brasil. In: CORTEZ, L.A.B. (Ed.). Bioetanol de cana-de-açúcar: P\&D para Produtividade Sustentabilidade. São Paulo: Edgard Blücher, 2010. p. 365-380.

CHERUBINI, F. The biorebinery concept: Using biomass instead of oil for producing energy and chemicals. Energy Conversion and Management, v. 51, p. 1412-1421, jan./ mar. 2010.

COMPANHIA NACIONAL DE ABASTECIMENTO. Acompanhamento da safra brasileira de gráos, v. 9 Safra 2015/16, Nono levantamento, Brasília, p. 1-178, junho 2016. Disponível em: <http://www.conab.gov.br/ OlalaCMS/uploads/arquivos/16_06_09_09_00_00_boletim_graos_junho_2016___final.pdf.> Acesso em: 24 nov. 2015.

COMPANHIA NACIONAL DE ABASTECIMENTO. A evoluçáo da soja no Brasil. [aplicativo]. [2016?] Disponível em: <http://www.cnpso.embrapa.br/sojaemnumeros/app/graf1.html> Acesso em: 24 nov. 2015.

Acompanhamento da Safra Brasileira Gráos, V.1 - Safra 2013/2014, n.12, Décimo segundo levantamento, Brasília, p. 1-127, set. 2014.

Acompanhamento da Safra Brasileira Gráos, v. 2 - Safra 2014/15, n. 12, Décimo segundo levantamento, Brasília, p. 1-134, set. 2015. Disponível em: <http://www.conab.gov.br/OlalaCMS/uploads/arquivos/15_09_11_10_42_03_boletim_graos_setembro_2015.pdf.> Acessado em: 23 nov. 2015.

CORBETT, D. B. et al. Chemical Composition of Apricot Pit Shells and Effect of Hot-Water Extraction. Energies, v. 8, p. 9640-9654, 2015.

DAVEBY, Y. D., AMAN, P. Chemical composition of certain dehulled seeds and their hulls with special reference to carbohydrates. Swedish Journal of Agricultural Research, p. 133-139. 1993.

DEMIRBAS, A. Biofuels sources, biofuel policy, biofuel economy and global biofuel projections. Energy Conversion and Management, v. 49, n. 8, p.2106-2116, 2008.

DURIGAN, J. C. et al. Períodos de matocompetição na cultura da soja (Glycine max (L.) Merril), cultivares Santa Rosa e IAC-2. I- efeitos sobre os parâmetros de produção. Planta Daninha, p. 86-100. 1983.

EICHLER, P. et al. Produção do biometanol via gaseificação de biomassa lignocelulósica. Quimica Nova, v. 38, n. 6, p. 828-835, 2015.

EMBRAPA CLIMA TEMPERADO. Cultivo do Arroz Irrigado no Brasil. Brasília: Embrapa, 2005. (Sistemas de Produção, 3).

EMPRESA BRASILEIRA DE PESQUISA AGROPECUÁRIA. Cultivo do Milho. Brasília: Embrapa, 2010. Disponível em: <http://www.cnpms.embrapa.br/publicacoes/milho_6_ed/manejomilho.htm>. Acesso em: 23 nov. 2015.

EMPRESA DE PESQUISA ENERGÉTICA. Balanço Energético Nacional 2013. Brasilia: EPE, 2013.

FOOD AND AGRICULTURE ORGANIZATION OF THE UNITED NATIONS. Statistics Division. [Homepage]. Disponível em: <http://faostat3.fao.org/home/E>. Acesso em: 29 Nov. 2015.

FAVARO, S. P., MIRANDA, C. H. B. Aproveitamento de Espécies Nativas e seus Coprodutos no contexto de Biorrefinaria. Brasília. DF: Embrapa Agroenergia, 2013.

FELDMAN, D. Lignin and Its Polyblends: a Review. In.: HU, T.Q. (Ed.). Chemical Modification, Properties, and Usage of Lignin. Boston, MA: Springer, 2002. p. 81-99.

FEIX, R. D., LEUSIN JÚNIOR, S. Painel do agronegócio no rio grande do sul - 2015. 2015. Disponível em: <http://www.fee.rs.gov.br/wp-content/ uploads/2015/09/20150903painel-do-agronegocio-no -rs-2015.pdf>. Acesso em: 23 nov. 2015.

FERREIRA, C. R. et al. Avaliação Tecnológica de Clones de Eucalipto: parte 1- qualidade damadeira para produção de celulose Kraft. Scientia Florestalis, n. 70, p. 161-170, 2006.

FLOUROS, A. I. et al. Note: Influence of the packaging material on the major volatile compounds of Tsipouro, a traditional Greek distillate. Food Science and Technology International, 9, 371-378, 2003. 
GALBE, M.; ZACCHI, G. Pretreatment of lignocellulosic materials for efficient bioethanol production. Advances in Biochemical Engineering/Biotechnology, n.108, p. 41-65, 2007.

GIANNELOS, P. N. et al. Tobacco seed oil as an alternative diesel fuel: physical and chemical properties. Journal Industrial crops and products. v. 16. n. 1. p. 1-9, 2002.

GONZÁLEZ-GONZÁlEZ, A. et al. Potential application of anaerobic digestion to tobacco plant. Journal Fuel. v 113, p. 415-19, 2013.

HE, L. et al. Enhanced hydrogen production from anaerobic fermentation of rice straw pretreated by hydrothermal technology. Bioresource Technology, v. 171, p. 145-151, 2014.

HIDENO, A. et al. Production and characterization of cellulases and hemicellulases by Acremonium cellulolyticus using rice straw subjected to various pretreatments as the carbon source. Enzyme and Microbial Technology, v. 48, p. 162-168, 2011.

HONGZHANG, C., BIN, Y., SHENGYING, J. Production of levulinic acid from steam exploded rice straw via solid superacid, $\mathrm{S}_{2} \mathrm{O}_{8}{ }^{2-} / \mathrm{ZrO}_{2}-\mathrm{SiO}_{2}-\mathrm{Sm}_{2} \mathrm{O}_{3}$. Bioresource Technology, v. 102, p. 3568-3570, 2011.

INSTITUTO BRASILEIRO DE GEOGRAFIA E ESTATÍSTICA. Levantamento Sistemático da Produçáo Agrícola. [2015?a]. Disponível em: < http://www.ibge. gov.br/home/estatistica/indicadores/agropecuaria/lspa/default.shtm>. Acesso em: 23 nov. 2015.

Safra de Uva. [2015?b] Disponível em: < https:// sidra.ibge.gov.br/home/lspa/brasil>. Acessado em: 19 out. 2015.

INSTITUTO RIOGRANDENSE DO ARROZ. Produção x Produtividade - RS - Gráfico. [2015?]. Disponível em: < http://www.irga.rs.gov.br/upload/20150720141753producao_rs_e_brasil_grafico.pdf> Acesso em: 28 nov. 2015.

LIN, K. H., HUANG, M. H., CHANG, A. C.C. Liquid phase reforming of rice straw for furfural production. International Journal of Hydrogen Energy, v. 38, p. 15794-15800, 2013.

LIU, C. M. et al. Biohydrogen production from rice straw hydrolyzate in a continuously external circulating bioreactor. International Journal of Hydrogen Energy, v. 39, p. 19317-19322, 2014.

LORA, E. E. S.; VENTURINI, O. J. Biocombustíveis. Rio de Janeiro: Interciência, 2010.
MABEE, W.E., MCFARLANE, P.N., SADDLER, J.N. Biomass availability for lignocellulosic ethanol production. Biomass and Bioenergy, v. 35, p. 4519-4529, 2011.

MAITY, S. K. Opportunities, recent trends and challenges of integrated biorefinery: Part I. Renewable and Sustainable Energy Reviews, v. 43, p. 1427-1445, 2015.

MENDES, J. A. S. et al.. Towards comprehensive utilization of winemaking residues: Characterization of grape skins from red grape pomaces of variety Touriga Nacional. Industrial Crop And Products. v. 43, p. 25-32, 2013.

MENEZES, R. R. et al. Obtenção de mulita porosa a partir da sílica da casca de arroz e do acetato de alumínio. Cerâmica, v. 54, p. 245-252, 2008.

MIELE. A. et al. Physicochemical composition, minerals, and pesticide residues in organic grape juices. Food Science And Technology, Campinas, v. 35, n. 1, jan./mar., 2015 .

NI, Y., WANG, Y., SUN, Z. Butanol production from cane molasses by Clostridium saccharobutylicum DSM 13864: batch and semicontinuous fermentation. Applied Biochemistry and Biotechnology, v. 166, n. 8, p18961907, 2012.

OCTAVE, S., THOMAS, D. Biorefinery: Toward an industrial metabolism. Biochimie, n. 91, p. 659-664, 2009.

OGUNNIYI, D. S.; ODETOYE, T. E. Preparation and evaluation of tobacco seed oil-modified alkyd resins. Journal Bioresource technology, v. 99, n. 5, p. 1300-1304, 2008.

OKAMOTO, K. et al. Direct ethanol production from starch, wheat bran and rice straw by the white rot fungus Trametes hirsuta. Enzyme and Microbial Technology, v. 48, p. 273-277, 2011.

PARANÁ. Departamento de Economia Rural. Fumo: análise de conjuntura agropecuária. 2012. Disponível em: <http://www.agricultura.pr.gov.br/arquivos/File/deral/ Prognosticos/fumo_2012_13.pdf.> Acesso em: 21 nov. 2015 .

PHITSUWAN, P., SAKKA, K., RATANAKHANOKCHAI, K. Improvement of lignocellulosic biomass in planta: A review of feedstocks, biomass recalcitrance, and strategic manipulation of ideal plants designed for ethanol production and processability. Biomass and Bioenergy, v. 58, p. 390-405, 2013.

PING, L. et al. Evaluation of grape stalks as a bioresource. Industrial Crops and Products, v. 33, p. 200-204, 2011. 
PUKASIEWICZ, S. R. M., OLIVEIRA, I. L., PILATTI, L. A. Estudo de caso: gerenciamento de resíduoas sólidos industriais em uma indústria processadora de soja. In: SIMPÓSIO DE ENGENHARIA DE PRODUÇÃO, 11., 2004, Bauru. Anais..., Bauru: Unesp, 2004.

RAMBO, M. K. D., SCHMIDT, F.L., FERREIRA, M.M.C. Analysis of the lignocellulosic components of biomass residues for biorefinery opportunities. Talanta, v. 144, p. 696-703, 2015.

RAMCHANDRAN, D. et al. Seasonal variability in ethanol concentrations from a dry grind fermentation operation associated with incoming corn variability. Industrial Crops and Products,.v.67, p.155-60, 2015.

RAMEZANI, A. et al. Evaluation of genetic diversity of Iranian grapevine accessions using microsatellite markers. Vitis, v. 48, n. 3, p. 151-152, 2009.

RAMOS, M. J. et al. Influence of fatty acid composition of raw materials on biodiesel properties. Bioresource Technology, v. 100, p. 261-268, 2009.

RANJAN, A.; MOHOLKAR, V. S. Comparative study of various pretreatment techniques for rice straw saccharification for the production of alcoholic biofuels. Fuel, v. 112, p. 567-571, 2013.

RODRIGUES, D. A. et al. Obtenção de açúcares a partir de cascas de arroz visando à produção de etanol de segunda geração. In: SEMINÁRIO JOVENS TALENTOS, 6., 2012, Santo Antônio de Goiás. Resumos apresentados. Santo Antônio de Goiás: Embrapa Arroz e Feijão, 2012

ROSA, M. F. et al. Valorização de Resíduos da Agroindústria. In: SIMPÓSIO INTERNACIONAL SOBRE GERENCIAMENTO DE RESÍDUOS AGROPECUÁRIOS E AGROINDUSTRIAIS, 2., Foz do Iguaçu. Palestras. Foz do Iguaçu, PR: [S.n.], 2011.

RUBERTO, G. et al. Volatile components of grape pomaces from different cultivars of Sicilian Vitis vinifera $L$. Bioresource Technology, n. 99, p. 260-268, 2008.

SANTOS, F., COLODETTE, J., QUEIROZ, J. H. Bioenergia e Biorrefinaria: Cana-de-Açúcar e Espécies Florestais. Viçosa: [S.n.], 2013.

SANTOS, F. A. et al. Potencial da Palha de cana-de-açúcar Para Produção de Etanol. Química Nova, v. 35, n. 5, p. 1004-1010, jan. 2012.

SANTOS, F. et al. Produção de etanol celulósico a partir da cana-de-açúcar. In: SANTOS, F.; COLODETTE, J.; QUEIROZ, J. H. (Eds). Bioenergia e Biorrefinaria: Ca-
na-de-Açúcar e Espécies Florestais. Viçosa: [S.n.], 2013. p. 129-164.

SCHULZ, H., Short History and Present Trends of Fischer-Tropsch synthesis. Applied Catalysis A: General, n. 186, p. 3-12, 1999.

SECRETARIA DE PLANEJAMENTO, MOBILIDADE E DESENVOLVIMENTO REGIONAL. Atlas socioeconômico - Rio Grande do Sul: soja .2011. Disponível em:<http://www.atlassocioeconomico.rs.gov.br/conteudo. asp?cod_conteudo=1488\&tipo_menu=ECONOMIA >. Acesso em: 22 nov. 2015.

SERVIÇO BRASILEIRO DE APOIO ÀS MICRO E PEQUENAS EMPRESAS. O cultivo e o mercado da uva. 2016. Disponível em: <http://www.sebrae.com.br/sites/ PortalSebrae/artigos/O-cultivo-e-o-mercado-da-uva>. Acesso em: 24 nov. 2015.

SHINOZAKI, Y.; KITAMOTO, H. K. Ethanol production from ensiled rice straw and whole-crop silage by the simultaneous enzymatic saccharification and fermentation process. Journal of Bioscience and Bioengineering, v.111, n. 3, p. 320-325, 2011.

SILVA, M. S. et al. Composição química e valor protéico do resíduo de soja em relação ao grão de soja. Ciência e Tecnologia de Alimentos, v. 26, n.3, p. 571-576, 2006.

SINDICATO INTERESTADUAL DA INDÚSTRIA DO TABACO. Perfil da propriedade. [2016?]. Disponível em:< http://sinditabaco.com.br/sobre-o-setor/estatisticas-e-infograficos/perfil-da-propriedade >. Acesso em: 23 nov. 2015.

SOUSA-AGUIAR, E. F. et al. Some important catalytic challenges in the bioethanol integrated biorefinery. Catalysis Today, v. 234, p. 13-23, 2014.

TIMIJENSEN, M. J. A., FAAIJ, A. P. C., HAMELINCK, M. R. M. Exploration of the Possibilities for production of Fischer Tropsch liquids and Power via biomass gasification. Biomass and Bioenergy, Pergamon, v. 23, p. 129152, mar. 2002.

TIMOFIECSYK, F. do R.; PAWLOWSKY, U. Minimizaçáo de Resíduos na Indústria de Alimentos: Revisão. Curitiba, v. 18, n.2, p. 221-236, 2000.

TOMES, D., LAKASHMANAN, P., SONGSTAD, D. (Eds). Biofuels: Global Impact on Renewable Energy, Production Agriculture, and Technological Advancements. [S.1.]: Springer, 2011.

UNITED STATES. United States Department of Agriculture. Corn Production. Disponível em: <http://www. 
indexmundi.com/agriculture/?commodity=corn> . Acesso em: 23 nov. 2015.

USTA, N. An experimental study on performance and exhaust emissions of a diesel engine fuelled with tobacco seed oil methyl ester. Energy conversion and management, v. 46, p. 2373-86, 2005 a.

USTA, N. Use of tobacco seed oil methyl ester in a turbocharged indirect injection diesel engine. Biomass and bioenergy, v. 28, p. 77-86. 2005b.

USTA, N. et al. Properties and quality verification of biodiesel produced from tobacco seed oil. Energy Conversion and Management, v. 52, p. 2031-39, 2011.

WAN, Y. et al. Evaluation of agronomic traits in Chinese wild grapes and screening superior accessions for use in a breeding program. Vitis, v.47, n. 3, p. 153-158, 2008.

WEILAND, P. Biogas Production: Current state and pesrpectives. Applied Microbiology and Biotechnology, Verlag, v. 85, p. 849-860, 2009.

WERBER, É. A. Excelência em Beneficiamento e Armazenagem de Gráos. Canoas: Sales, 2005, p. 586.

YANG, S.T.; YU, M. Bioprocessing Technologies in Biorefinery for Sustainable Production of Fuels, Chemicals, and Polymers. [S.1.]: John Wiley \& Sons, 2013.

ZHANG, H. et al. A new method of utilizing rice husk: Consecutively preparing $\mathrm{D}$-xylose, organosolv lignin, ethanol and amorphous superfine silica. Journal of Hazardous Materials, v. 291, p. 65-73, 2015. 